\title{
EXPLORING \\ THE DISTANCE EDUCATION STUDENTS' CYBERBULLYING, CYBERVICTIMIZATION AND CYBERBULLYING SENSIBILITY LEVELS
}

\author{
Assist. Prof. Dr. Hasan OZGUR \\ Faculty of Education, Trakya University \\ Edirne, TURKEY
}

\section{ABSTRACT}

The purpose of present research is to detect cyberbullying, cybervictimization and cyberbullying sensibility levels of distance education students and analyze these levels with respect to several variables. The research has been patterned on relational screening model. Study group consisted of $\mathbf{2 9 7}$ distance education students studying at university in Marmara region during fall term of 2012-2013 academic year. Data have been obtained via cyberbullying scale, cybervictimization scale and cyberbullying sensibility scale. In the analysis of obtained data descriptive statistics, Mann Whitney $U$, Kruskal Wallis $H$ and correlation tests have been utilized. Obtained findings manifested that distance education students received low scores on cyberbullying and mid level scores from cybervictimization; that they possess high sensibility towards cyberbullying and there is statistically meaningful differentiation between cyberbullying and cybervictimization. It has also been detected that the increase in Internet usage has accelerating effect on cyberbullying and cybervictimization and that there is correlation between cyberbullying and cybervictimization. Furthermore it has been revealed that compared to female students male students are engaged in higher levels of cyberbullying and they become cybervictimized more frequently.

Keywords: Cyberbullying, Cybervictimization, Cyberbullying Sensibility, Distance Education.

\section{INTRODUCTION}

Recent rise in the use of information and communication technologies has correspondingly altered people's learning methods and tools, social communications and sense of fun to a higher extent. In addition to the great changes information and communication technologies has introduced into people's social lives, it has -as expected from any technology- also brought about with itself several adversities (Shariff, 2009; Yaman, Eroglu \& Peker, 2011). Uncontrolled use of information and communication technologies has triggered the rise of conflicts in human relations, deteriorations in mental health and emergence of new addiction types originating from information and communication technologies (Ceyhan \& Ceyhan, 2008; Chak \& Leung, 2004; Hinduja \& Patchin, 2008).

Abuse of information and communication technologies has triggered the birth of a new bullying type called cyber bullying. In relevant literature cyber bullying has many other corresponding terms such as virtual bullying, electronic bullying (Willard, 2005), techno bullying and online bullying (Akbulut, Sahin \& Eristi, 2010). In the words of Campbell 
(2005), cyberbullying is using various forms of technology such as electronic mail, instant messaging, chat rooms and websites to psychologically torment other parties.

Hinduja and Patchin (2010) on the other hand explain cyberbullying as intentional and repetitive usage of computers, mobile phones and similar electronic tools to torment others. Mason (2008) reports that cyberbullying is the use of communication technologies for the aim of sending or publishing coarse notes and/or images by a person or group to another person or group to intentionally and repetitively harass or threaten the addressee. In a broader definition cyberbullying is described as the sum of all behaviors (Aricak, 2011; Belsey, 2007; Lacey, 2007; Yaman et al., 2011) conducted via computers, mobile phones and other communication technologies to cause damages in a person's or group's social or technical connections and this social attack has an intentional and repetitive character. According to Willard (2005) cyberbullying is sending furious and coarse messages, harassing the addressee by sending repetitive and frequent insult messages, sending defaming or humiliating messages to undermine addressee's reputation and friendships, by pretending to be someone else, sending graphic or text messages to unease the addressee or to undermine addressee's reputation and friendships, sharing on electronic environment private or humiliating information or photos of people, obtaining a person's personal secrets or humiliating personal information and employing certain methods to publish such information on virtual environment, intentionally and brutally discarding a person from an online group or environment, continuous and intense harassment or critical traumatization and defaming of the addressee.

In literature as researches on cyberbullying are analyzed with respect to gender variable it can be observed in some researches that males are more inclined towards cyberbullying when compared to females (Ayas \& Horzum, 2012; Calvete, Orue, Estévez, Villardón \& Padilla, 2010; Cetinkaya, 2010; Erdur-Baker, 2010) whereas some research findings have contrarily manifested that girls are more inclined towards cyberbullying behaviors than boys (Agatston, Kowalski \& Limber, 2007; Keith \& Martin, 2005; Li, 2006). As researches on cyberbullying are analyzed with respect to cybervictimization, some researchers claim that girls face greater levels of victimization than boys (Mesch, 2009; Ybarra, Mitchell, Wolak \& Finkelhor, 2006) whilst another group of researchers argue that there exists no statistically meaningful differentiation between girls and boys with respect to being victimized by cyberbullying (Özdemir \& Akar, 2011; Peker, Eroglu \& Citemel, 2012; Slonje \& Smith, 2008). In a number of literature studies interrogating cyberbullying sensibility level with respect to gender variable, a meaningful differentiation has been detected (Ayas \& Horzum, 2011) while in some studies, no differentiation could be verified (Gezgin \& Cuhadar, 2012; Huang \& Chou, 2013).

Another finding obtained in relevant literature is that there might be connection between Internet usage frequency and cyberbullying (Akbulut et al., 2010; Erdur-Baker 2010; Li, 2006; Topcu, Erdur-Baker \& Capa-Aydin, 2008; Ozdemir \& Akar, 2011; Wolak, Mitchell \& Finkelhor, 2007). Likewise Erdur-Baker and Kavsut (2007) have reported that there is positive correlation between the usage of Internet-based communication resources and being a cyberbully or being a cyberbullying victim. In literature it is possible to come across research findings manifesting that there is no meaningful differentiation between frequency of Internet usage and sensibility level towards cyberbullying (Gezgin \& Cuhadar, 2012).

In some literature studies exploring the connection between age and grade variables and being a cyberbully or being a cyberbullying victim it has been claimed that no relation exists cyberbullying or cybervictimization with respect to aforementioned variables (Burnukara, 2009; Erdur-Baker \& Kavsut, 2007; Ozdemir \& Akar, 2011; Slonje \& Smith, 2008), while findings of some researches indicated that there is a connection between cyberbullying and cybervictimization with respect age and grade variables (Ayas \& 
Horzum, 2012; Kowalski \& Limber, 2007; Mark, 2009; Pepler, Craig, Connolly, Yuile, McMaster \& Jiang, 2006). In relevant literature there are also a number of researches underlining that there is no relation between these particular variables and sensibility level towards cyberbullying (Ayas \& Horzum, 2011; Gezgin \& Cuhadar, 2012).

In literature researches probing into the relation between cyberbullying and cybervictimization it has been designated that the most powerful predictor of cyberbullying performance is cybervictimization or in other way, the most powerful predictor of cybervictimization is cyberbullying (Akbulut \& Eristi, 2011; Bauman, 2010; Bauman \& Pero, 2010), that cybervictimization is the most salient factor in cyberbullying (Hoff \& Mitchell, 2010), that there is high possibility that cyberbullying victims shall eventually perform cyberbullying behaviors (Erdur-Baker, 2010; Walrave \& Heirman, 2011).

As literature researches on cyberbullying, cybervictimization or cyberbullying sensibility are examined it can be detected that a majority of researches conducted in Turkey have covered formal education teenagers or developmental age students and college students (Aricak, 2009; Ayas \& Horzum, 2012; Cetinkaya, 2010; Gezgin \& Cuhadar, 2012; Ozdemir \& Akar, 2011; Sahin 2012). On the other hand in relevant literature studies it has also been ascertained that cyberbullying is the common problem shared amid all individuals regardless of age, education and socio-economic level (Akbulut \& Eristi, 2011), that the rise in the frequency of Internet based communication resources enhanced the likelihood of cyberbullying or cybervictimization (Erdur-Baker \& Kavsut, 2007). Accordingly, as manifested in Turkish Statistics Institute's (TUIK, 2012) national statistics demonstrating that of the teenagers between age sixteen and twenty four $67.7 \%$ and of the adults between age twenty five and thirty four $58.5 \%$ use the Internet which indicates that a great portion of society is under the risk of being either a cyberbully or cyberbullying victim hence it is essential to conduct further researches covering different groups of age. On the other hand according to data from Turkish Higher Education Institute, though there are more than two millions of distance education students in Turkey, there are no literature research that collectively analyzes these students' cyberbullying, cybervictimization and cyberbullying sensibility level which further emphasizes the gravity of this research. Hence it has been deemed essential to conduct current research that analyzes cyberbullying, cybervictimization and cyberbullying sensibility levels of distance education students with respect to several variables.

\section{PURPOSE OF THE STUDY}

As literature researches on cyberbullying, cybervictimization or cyberbullying sensibility are examined it can be detected that a majority of researches conducted in Turkey have covered formal education teenagers or developmental age students and college students (Aricak, 2009; Ayas \& Horzum, 2012; Cetinkaya, 2010; Gezgin \& Cuhadar, 2012; Ozdemir \& Akar, 2011; Sahin 2012). On the other hand in relevant literature studies it has also been ascertained that cyberbullying is the common problem shared amid all individuals regardless of age, education and socio-economic level (Akbulut \& Eristi, 2011), that the rise in the frequency of Internet based communication resources enhanced the likelihood of cyberbullying or cybervictimization (Erdur-Baker \& Kavsut, 2007). Accordingly, as manifested in Turkish Statistics Institute's (TUIK, 2012) national statistics demonstrating that of the teenagers between age sixteen and twenty four $67.7 \%$ and of the adults between age twenty five and thirty four $58.5 \%$ use the Internet which indicates that a great portion of society is under the risk of being either a cyberbully or cyberbullying victim hence it is essential to conduct further researches covering different groups of age. On the other hand according to data from Turkish Higher Education Institute, though there is more than two millions of distance education students in Turkey, there are no literature research that collectively analyzes these students' cyberbullying, cybervictimization and cyberbullying sensibility level which further emphasizes the 
gravity of this research. Hence it has been deemed essential to conduct current research that analyzes cyberbullying, cybervictimization and cyberbullying sensibility levels of distance education students with respect to several variables.

\section{METHOD}

This research is a descriptive research. In the research, relational screening model was employed. According to Karasar (2008), relational screening model aims to determine the change or levels of the change between two or more variables. The relations found through screening are not necessarily cause-effect relations; however the situation identified in variable may give hints about the other variable(s). In this context, the relationship between cyberbullying, cybervictimization and cyberbullying sensibility of studensts was analysed through correlation oriented relational screening model. The comparative relational screening model was used in order to determine whether there is a difference between gender, grade, enrolled program, age, the frequency of Internet use variables.

\section{Participants}

Population of this research comprised of 297 distance education students studying at Trakya University, Tunca Vocational High School during fall term of 2012-2013 academic year. Of the research participants, 95 are (32\%) females and 202 are (68\%) males. 121 of students are 1st graders $(40.7 \%)$ and 176 are 2 nd graders $(59.3 \%)$. Of the participant students $58(19.5 \%)$ access the Internet one-two hours in a day, 78 students $(26.3 \%)$ three-four hours in a day and 161 students $(36.7 \%)$ five or longer hours in a day. 49 students study in (16.5\%) Information Management department, 42 in (14.1\%) Business Administration department and 206 in (69.4\%) Computer Programming department. Of the distance education students, 165 are $(55.6 \%)$ between age eighteen and twenty five, 104 are $(35.0 \%)$ between age twenty six and thirty three and 28 are $(9.4 \%)$ between age thirty four and above. 56 of students $(18.9 \%)$ claimed to have been a victim of cyberbullying before and 27 students $(9.1 \%)$ claimed to have performed cyberbullying behavior.

\section{Data Collection Tools}

Cyberbullying scale: towards the aim of gathering students' views on cyberbullying performance Cyberbullying Scale developed by Aricak, Kinay and Tanrikulu (2012) has been utilized. The scale consists of single factor which explains $50.58 \%$ of total variance. Factor loads of items vary between.49 and .80. Cronbach's Alpha coefficient calculated for the entire scale has been detected as.95; test-re test reliability coefficient as .70 . The scale comprises of 24 items and answered on a four-choice scale (Never, Sometimes, Usually and Always). Scoring of scale is as never $=1$, sometimes $=2$, usually=3 and always=4. Minimum score to receive from the scale is 24 , maximum score is 96 . The higher score received from the scale indicates that the person is a cyberbully (Aricak et al., 2012). In present research, Cronbach's Alpha internal consistency coefficient of the scale has been computed as .92.

\section{Cybervictimization Scale}

Towards the aim of detecting if students are cybervictimized, Cybervictimization Scale developed by Aricak, Tanrikulu and Kinay (2012) has been employed. The scale consists of single factor which explains $30.17 \%$ of total variance. Factor loads of items vary between .43 and .67. Cronbach's Alpha coefficient calculated for the entire scale has been detected as .89; test-re test reliability coefficient as .75. The scale comprises of 24 items and answered on two- choice scale (Yes-No). Scoring of scale is as yes=2, no=1. Minimum score to receive from the scale is 24, maximum score is $\mathbf{4 8}$. The higher score received from the scale indicates that the person is a cyberbullying victim (Aricak et al., 2012). In present research, Cronbach's Alpha internal consistency coefficient of the scale has been computed as .87 . 


\section{Cyberbullying Sensibility Scale}

Towards the aim of detecting students' sensibility towards cyberbullying, Cyberbullying Sensibility Scale developed by Tanrikulu, Kinay and Aricak (2013) has been employed. The scale consists of single factor which explains $46.65 \%$ of total variance. Factor loads of items vary between .32 and .73 . Internal consistency coefficients of the scale have been found as .83 and .90; two half test-reliability coefficients between .75 and .84 .

In addition, item-total correlations of the scale have been lined between .42 and .63 for integrated group. Consisting of 14 items the scale is answered on three-choice scale (Yes, Sometimes, No). Scoring of scale is as $n o=1$, sometimes $=2$ and yes $=3$. Minimum score to receive from the scale is 14 , maximum score is 42 . The higher score obtained from the scale indicates that the student has high level of sensibility towards cyberbullying (Tanrikulu et al, 2013). In present research Cronbach's Alpha internal consistency coefficient of scale has been detected as .82 .

\section{Data Collection and Analysis}

Data have been collected by the researcher during 2012-2013 academic year fall term pre-final exams period. First, students have been briefed on research topic and data collection tools. Next they have been reminded that research participation is voluntary, then students have been directed towards survey questions. The scales have been answered in about 20 minutes. Throughout the process 305 surveys in total have been distributed to students and 297 of these surveys have been received back in a format applicable to data processing. Prior to the analysis Kolmogorov-Smirnov Test has been conducted to see if data were in normal distribution and it has been detected that for the variables, test result is $\mathbf{p}<\mathbf{0 . 0 5}$. Towards the aim of analyzing data with no normal distribution descriptive statistics, Mann Whitney $U$ and Kruskal Wallis $\mathrm{H}$ tests have been utilized. To the end of detecting inter-scale relation, Spearman Brown Rank Correlation coefficient has been employed. In the correlations .05 level of significance has been taken as meaningful.

\section{FINDINGS}

Correlation coefficients amid cyberbullying, cybervictimization and cyberbullying sensibility variables have been demonstrated in Table 1 . As Table 1 is examined it surfaces that between cyberbullying and cybervictimization there is mid-level, positive and meaningful correlation $(r=.327, p<.01)$. It can thus be argued in the light of this finding that parallel to the increase in cybervictimization, cyberbullying also grows bigger.

Table: 1

Correlations between the cyberbullying, cybervictimization and cyberbullying sensibility variables

\begin{tabular}{lccc}
\hline Variables & Cyberbullying & Cybervictimization & Cyberbullying Sensibility \\
\hline Cyberbullying & & $.327 * *$ & .028 \\
Cybervictimization & $.327 * *$ & & $.147 *$ \\
Cyberbullying Sensibility & .028 & $.147 *$ & \\
\hline
\end{tabular}

Note. ${ }^{*} \mathrm{p}<.05, * * \mathrm{p}<.01$

Taken into account the determination coefficient as well $\left(r^{2}=0.11\right)$ it can be claimed that $11 \%$ of total variance in cybervictimization stems from cyberbullying. Likewise it can also be identified that between cybervictimization and sensibility towards cyberbullying, there is low level, positive and meaningful correlation $(r=.147, p<.05)$. Obtained findings on cyberbullying, cybervictimization and sensibility towards cyberbullying manifest that students' average scores on cyberbullying $(\bar{X}=32.31)$ and cybervictimization $(\bar{X}=30.36)$ 
are mid-level whereas the score average obtained from cyberbullying sensibility scale is significantly high ( $\bar{X}=36.62)$. Obtained findings are as shown in Table 2.

Table: 2

Descriptive statistics of the distance education students for cyberbullying, cybervictimization and cyberbullying sensibility scores

\begin{tabular}{lccc}
\hline \multicolumn{1}{c}{ Variables } & $\mathbf{N}$ & $\bar{X}$ & SD \\
\hline Cyberbullying & 297 & 32.31 & 11.02 \\
Cybervictimization & 297 & 30.36 & 3.86 \\
Cyberbullying Sensibility & 297 & 36.62 & 5.31 \\
\hline
\end{tabular}

Mann Whitney $U$ Test has been employed to analyze distance education students' cyberbullying, cybervictimization and sensibility levels towards cyberbullying with respect to gender variable. According to the findings listed in Table 3, with respect to gender variable, there is meaningful differentiation between cyberbullying and cybervictimization scores $\left(U_{1}=8079.00, p<.05 ; U_{2}=8214.00, p<.05\right)$.

Table: 3

Mann-Whitney $U$ test result of cyberbullying, cybervictimization and cyberbullying sensibility scores with respect to the variable of gender

\begin{tabular}{llccccc}
\hline Variables & Gender & $\mathbf{N}$ & $\begin{array}{c}\text { Mean } \\
\text { Rank }\end{array}$ & Sum of Ranks & U & p \\
\hline Cyberbullying & Male & 202 & 156.50 & 31614.00 & 8079.00 & .019 \\
& Female & 95 & 133.04 & 12639.00 & & \\
Cybervictimization & Male & 202 & 155.84 & 31479.00 & 8214.00 & .043 \\
& Female & 95 & 134.46 & 12774.00 & & \\
Cyberbullying Sensibility & Male & 202 & 151.82 & 30668.50 & 9024.50 & .406 \\
& Female & 95 & 145.95 & 13584.50 & & \\
\hline
\end{tabular}

The correlation between grades of distance education students and the levels of cyberbullying, cybervictimization and sensibility level towards cybervictimization has been examined via Mann Whitney $U$ Test. According to findings presented in Table 4, with respect to grade variable, there is no meaningful differentiation amid cyberbullying, cybervictimization and sensibility towards cyberbullying scores $\left(U_{1}=9575.50, p>.05\right.$; $\left.U_{2}=9612.50, p>.05 ; U_{3}=9409.50, p>.05\right)$.

Table: 4

Mann-Whitney $\mathrm{U}$ test result of cyberbullying, cybervictimization and cyberbullying sensibility scores with respect to the variable of grade

\begin{tabular}{lllcccc}
\hline Variables & Class & N & Mean Rank & Sum of Ranks & U & p \\
\hline Cyberbullying & 1st graders & 121 & 157.86 & 19101.50 & 9575.50 & .117 \\
& 2nd graders & 176 & 142.91 & 25151.50 & & \\
Cybervictimization & 1st graders & 121 & 140.44 & 16993.50 & 9612.50 & .149 \\
& 2nd graders & 176 & 154.88 & 27259.50 & & \\
Cyberbullying Sensibility & 1st graders & 121 & 159.24 & 19267.50 & 9409.50 & .087 \\
& 2nd graders & 176 & 141.96 & 24985.50 & & \\
\hline
\end{tabular}

Towards the aim of analyzing distance education students' levels of cyberbullying, cybervictimization and sensibility level towards cybervictimization with respect to their department Kruskal Wallis $H$ Test has been employed. According to findings presented in Table 5, with respect to department variable, there is no meaningful differentiation amid cyberbullying, cybervictimization and sensibility towards cyberbullying scores $X_{1}{ }^{2}(d f=2$, $n=297)=4.68, p>.05 ; X_{2}^{2}(d f=2, n=297)=.58, p>.05 ; X_{3}^{2}(d f=2, n=297)=3.50, p>.05$. 
Table: 5

Kruskal Wallis $\mathbf{H}$ test result of cyberbullying, cybervictimization and cyberbullying sensibility scores with respect to the variable of program of study

\begin{tabular}{llccccc}
\hline Variables & Program of Study & N & Mean Rank & df & $X^{2}$ & p \\
\hline \multirow{3}{*}{ Cyberbullying } & Business Administration & 42 & 158.18 & 2 & 4.68 & .096 \\
& Information Management & 49 & 126.62 & & & \\
& Computer Programming & 206 & 152.45 & & & \\
Cybervictimization & Business Administration & 42 & 155.92 & 2 & .58 & .745 \\
& Information Management & 49 & 142.28 & & & \\
Cyberbullying & Computer Programming & 206 & 149.19 & & & \multirow{2}{*}{ (20.53 } \\
Sensibility & Business Administration & 42 & 141.43 & 2 & 3.50 & .173 \\
& Information Management & 49 & 169.64 & & & \\
\hline
\end{tabular}

Towards the aim of analyzing distance education students' levels of cyberbullying, cybervictimization and sensibility level towards cybervictimization with respect to their age, Kruskal Wallis H Test has been employed.

According to analysis findings, with respect to age variable, there is no meaningful differentiation amid cyberbullying, cybervictimization and sensibility towards cyberbullying scores $X_{1}^{2}(d f=2, n=297)=5.48, p>.05, X_{2}{ }^{2}(d f=2, n=297)=.38, p>.05$ and $X_{3}^{2}(d f=2, n=297)=5.38, p>.05$. Obtained findings have been presented in Table 6.

Table: 6

Kruskal Wallis $\mathbf{H}$ test result of cyberbullying, cybervictimization and cyberbullying sensibility scores with respect to the variable of age

\begin{tabular}{llccccc}
\hline \multicolumn{1}{c}{ Variables } & \multicolumn{1}{c}{ Age } & N & Mean Rank & df & $\chi^{2}$ & p \\
\hline Cyberbullying & $18-25$ & 165 & 157.38 & 2 & 5.48 & .064 \\
& $26-33$ & 104 & 142.97 & & & \\
Cybervictimization & 34 and over & 28 & 122.02 & & & \\
& $18-25$ & 165 & 151.10 & 2 & .38 & .825 \\
Cyberbullying Sensibility & $26-33$ & 104 & 144.86 & & & \\
& 34 and over & 28 & 152.00 & & & \\
& $18-25$ & 165 & 138.73 & 2 & 5.38 & .068 \\
& $26-33$ & 104 & 161.18 & & & \\
\hline
\end{tabular}

Towards the aim of analyzing distance education students' levels of cyberbullying, cybervictimization and sensibility level towards cyberbullying with respect to daily use frequency of Internet, Kruskal Wallis H Test has been employed.

Analysis findings demonstrate that between Internet use frequency variable and cyberbullying and cybervictimization score there is meaningful differentiation $X_{1}{ }^{2}(d f=2$, $n=297)=10.43, p<.05$ and $X_{2}^{2}(d f=2, n=297)=9.85, p<.05$.

This finding proves that increase in daily use length of Internet is an effective factor on cyberbullying and cybervictimization.

As rank averages are taken into consideration it is detected that cyberbullying is maximum in students spending five or longer hours on the Internet and cybervictimization is maximum in students spending three-four hours in a day on the Internet. Obtained findings are as demonstrated in Table 7. 
Table: 7

Kruskal Wallis $\mathrm{H}$ test result of cyberbullying, cybervictimization and cyberbullying sensibility scores with respect to the variable of internet use frequency

\begin{tabular}{|c|c|c|c|c|c|c|c|}
\hline Variables & $\begin{array}{l}\text { Internet use } \\
\text { frequency }\end{array}$ & $\mathbf{N}$ & $\begin{array}{l}\text { Mean } \\
\text { Rank }\end{array}$ & df & $x^{2}$ & $\mathbf{p}$ & Significance \\
\hline \multirow{3}{*}{ Cyberbullying } & 1or 2 hours (A) & 58 & 118.81 & 2 & 10.43 & .005 & C-A \\
\hline & 3 or 4 hours (B) & 78 & 151.89 & & & & \\
\hline & 5 hours and more $(C)$ & 161 & 158.48 & & & & \\
\hline \multirow[t]{2}{*}{ Cybervictimization } & $\begin{array}{l}1 \text { or } 2 \text { hours (A) } \\
3 \text { or } 4 \text { hours (B) }\end{array}$ & $\begin{array}{l}58 \\
78\end{array}$ & $\begin{array}{l}122.23 \\
168.40\end{array}$ & 2 & 9.85 & .007 & B-A, C-A \\
\hline & 5 hours and more (C) & 161 & 149.25 & & & & \\
\hline \multirow{3}{*}{$\begin{array}{l}\text { Cyberbullying } \\
\text { Sensibility }\end{array}$} & 1or 2 hours (A) & 58 & 138.93 & 2 & 1.08 & .582 & \\
\hline & 3 or 4 hours (B) & 78 & 149.14 & & & & \\
\hline & 5 hours and more $(C)$ & 161 & 152.56 & & & & \\
\hline
\end{tabular}

In order to identify the source of difference detected between groups Mann Whitney Utests have been employed on dual combinations of groups. Test findings manifested that students performing cyberbullying behaviors spend five or longer hours of time on the Internet.

In the evaluation based on the cybervictimizations of students it has been detected that between three-four or longer hours of daily Internet use and one-two hours of daily Internet use there is meaningful differentiation. In another saying students spending three-four or longer hours on the Internet in a day exhibit higher tendency towards cybervictimization.

Towards the aim of analyzing distance education students' levels of cyberbullying, cybervictimization and sensibility level towards cyberbullying with respect to having experienced any type of cyberbullying victimization before, Mann Whitney $U$ Test has been utilized and obtained findings are as shown in Table 8.

Accordingly there is meaningful differentiation between variable of experiencing cyberbullying victimization before and performing cyberbullying behavior $(U=5589.50$, $p<.05)$. In the light of this finding it is feasible to argue that students having experienced cyberbullying victimization tend to perform cyberbullying behavior in future.

Table: 8

Mann-Whitney $U$ test result of cyberbullying and cyberbullying sensibility scores with respect to having exposed to cyberbullying,

\begin{tabular}{llccccc}
\hline Variables & Group & N & Mean Rank & Sum of Ranks & U & p \\
\hline Cyberbullying & Exposed & 56 & 169.69 & 9502.50 & 5589.50 & .033 \\
& Not exposed & 241 & 144.19 & 34750.50 & & \\
Cyberbullying & Exposed & 56 & 160.68 & 9007.50 & 6084.50 & .250 \\
Sensibility & Not exposed & 241 & 146.25 & 35245.50 & & \\
\hline
\end{tabular}

In order to detect if students sensibility levels towards cybervictimization and cyberbullying varied with respect to their past experiences (if any) with any cyberbullying Mann Whitney U Test has been utilized.

As manifested in the findings in Table 9, there is meaningful differentiation between variable of cyberbullying and cybervictimization $(U=555.00, p<.05)$. According to this finding there is meaningful correlation between students' cyberbullying and cybervictimization. 
Table: 9

Mann-Whitney $U$ test result of cybervictimization and cyberbullying sensibility scores with respect to the variable of engage in cyberbullying as a bully

\begin{tabular}{llccccc}
\hline \multicolumn{1}{c}{ Variables } & Group & $\mathrm{N}$ & Mean Rank & Sum of Ranks & U & $\mathrm{p}$ \\
\hline Cybervictimization & Engaged & 27 & 204.39 & 5518.50 & 555.00 & .000 \\
& Not engaged & 270 & 137.56 & 38734.50 & & \\
Cyberbullying & Engaged & 27 & 174.20 & 4703.50 & 2694.50 & .108 \\
Sensibility & Not engaged & 270 & 146.48 & 39549.50 & & \\
\hline
\end{tabular}

\section{DISCUSSIONS and CONCLUSION}

The objective in present research has been to detect distance education students cyberbullying, cybervictimization and sensibility levels towards cyberbullying with respect to different variables. Obtained findings manifest that cyberbullying performance scores of distance education students are low, cybervictimization scores are mid-level and there is mid-level correlation between two. It has also been manifested that there is meaningful differentiation between cybervictimization variable and cyberbullying. Likewise it has been detected that there is meaningful differentiation between cyberbullying variable and cybervictimization. In another saying these findings indicate that cyberbullying and cybervictimization are two factors triggering one another. In relevant literature it is possible to come across several researches echoing the findings of current study (Akbulut \& Eristi, 2011; Bauman, 2010; Erdur-Baker, 2010; Çelik, Atak \& Erguzen, 2012; Kowalski \& Limber, 2007; Walrave \& Heirman, 2011; Ybarra \& Mitchell, 2004). Some of the findings obtained from researches on cyberbullying report that when students are exposed to cyberbullying they develop feelings of anger, hatred, disappointment and revenge (Sahin, Sari, Ozer \& Er, 2010) and once fueled with these adverse feelings those victims of cyberbullying can themselves turn into potential cyberbullies ( $\mathrm{Li}, \mathbf{2 0 0 6})$.

This finding can be construed in this way: individuals personally victimized by cyberbullying behaviors can cultivate lessened sensitivity due to the effects of negative feelings such as hatred, anger and humiliation.

Another finding obtained from this research is that students have high sensitivity levels towards cyberbullying and that there is weak connection with cybervictimization. In another saying it is argued that people who are aware that via Internet or mobile tools their personal information might be abused by bad intentional interrupters, that they should terminate communication once meet curses or scoffs on virtual environment and people who take required measures to ensure that neither communication tool nor the person gets defiled in virtual environment are less likely to be victimized by cyberbullying.

Another finding detected is that with respect to gender variable there is meaningful differentiation between being a cyberbully and being a cybervictim as regards distance education students. Finding obtained from this research is parallel to the relevant literature reporting that compared to females males are engaged in cyberbullying actions more frequently (Ayas \&Horzum, 2012; Özdemir \& Akar, 2011; Şahin et al., 2010), and that they are more victimized by cyberbullies (Akbulut \& Eristi, 2011; Aricak et al., 2008; Erdur-Baker, 2010; Erdur-Baker \& Kavsut, 2007; Li, 2006). On the other hand other findings claiming that females perform higher numbers of cyberbullying actions than males (Agatston et al., 2007; Keith \& Martin, 2005; Li, 2006) and that they are victimized more compared to males (Mesch, 2009; Ybarra et al., 2006) and other research findings arguing that with respect to cybervictimization there is no meaningful differentiation between females and males (Özdemir \& Akar, 2011; Peker et al., 2012; Slonje \& Smith, 
2008) are not parallel to the finding detected in present research. It can be argued that such dissimilarity might be attributed to the fact that Turkish society is a maledominated, patriarchal community and as gender rule of socialization girls are, compared to boys, more inclined towards obeying social norms (Akbulut \& Eristi, 2011). It can also be suggested that TUIK (2012) data claiming that males are more inclined to information and communication technologies might have been effective in obtaining this finding. Within that context it is believed that it would be contributive to the related field to conduct researches that analyze on different groups bullying performances specific to girls and boys separately.

One other finding obtained from this research is that with respect to department, age and grade variables and cyberbullying, cybervictimization and sensibility towards cyberbullying scores, there exists no meaningful differentiation. In relevant literature the researches that focus on the relation between cyberbullying and cybervictimization with respect to age, grade and department variables provide similar results to the findings of current research (Burnukara, 2009; Erdur-Baker \& Kavsut, 2007; Özdemir \& Akar, 2011; Slonje \& Smith, 2008). On the other hand there are some researches evidencing that with respect to age and grade variable there is a relation between cyberbullying and cybervictimization (Ayas \& Horzum, 2012; Kowalski \& Limber, 2007; Mark, 2009; Pepler, et al., 2006).

There are also a number of studies reporting that there is no correlation between sensibility towards cyberbullying and variables aforementioned (Ayas \& Horzum, 2011; Gezgin \& Cuhadar, 2012). Sampling of literature studies that differ from the finding of present research consists of children or teenagers whereas sampling in this research is consisted of adult students. It is considered that the difference between findings of this research and findings of other researches might stem from the fact that adults use Internet based communication resources and novel technologies more deliberatively when compared to children or teenagers and that they are more aware of the negative effects of these resources and technologies. Indeed, European Online Kids Research Turkey Report (EU Kids Online, 2012) stating that kids possess low level of knowledge and skills on the Internet use is supportive of this deduction. In order to manifest more accurately the reasons of this difference emerging in literature researches, comparative qualitative and quantitative researches need to be conducted.

Another finding of this research is that with respect to variable of daily Internet use of distance education students there is meaningful differentiation between cyberbullying and cybervictimization. In another saying it has been detected that children who spend five or longer hours daily on the Internet perform greater levels of cyberbullying when compared to students spending fewer hours. This finding is parallel to many other researches in relevant literature (Akbulut et al., 2010; Erdur-Baker 2010; Hinduja \& Patchin, 2008; Li, 2005; Ozdemir \& Akar, 2011; Topcu et al., 2008). This finding may be attributed to the assumption that children spending longer time on the Internet may be engaged in more negative shares parallel to the rise in this length. This research finding has also demonstrated that students spending three or four hours on the Internet are, compared to the children spending less time, victimized by cyberbullying to a greater extent.

This finding is also parallel to results obtained from relevant literary researches (Peker \& Eroglu 2010). In the research, finding indicating the relation between daily Internet use and cybervictimization has demonstrated that the rise of Internet use to five or longer hours triggered a fall in the scores of cybervictimization.

This finding is also parallel to one of the other findings of research indicating that increase in the frequency of Internet use has accelerating effect on sensibility towards cyberbullying. 
This finding can be construed in such way; the increase in the Internet use of participants created a boosting effect on their awareness on cyberbullying hence they were less victimized by cyberbullying. Towards the aim of analyzing this research finding more safely it would be useful to conduct further researches to examine the relation between Internet use frequency and cybervictimization on groups with dissimilar demographical characteristics.

Considering the fact that information and communication technologies are utilized more widely and heavily every passing day, it would be useful to analyze cyberbullying which is becoming increasingly common in not only Turkey but the whole globe amid teenagers and adults and bringing forth devastating effects under new researches that cover a variety of groups and elevating the sensitivity of general society towards cyberbullying would contribute greatly to the solution of this prevailing problem.

There are a number of limitations concerning this study. The main limitation is that all analyses have been built upon single group of data hence it is essential that findings obtained from present research should be verified by comparing and contrasting with findings obtained from distance education students studying at different departments in different universities. Findings obtained via quantitative research methods in present study should also be consolidated with research findings obtained via qualitative methods. Questions such as "What are the relations of socio demographic features excluded from the scope of this research with cyberbullying and cybervictimization? Towards the aim of coping with cyberbullying problem, what are communication features of cyberbullies and cybervictims on virtual environment? What views are held by cybervictims concerning cyberbullying?" should be sought for answers in future studies integrated with qualitative or quantitative qualities.

\section{BIODATA and CONTACT ADDRESSES of the AUTHOR}

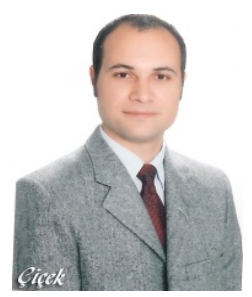

Dr. Hasan OZGUR was born in Burgaz, Bulgaria, in 1980. He graduated from Marmara University, Faculty of Education, Department of Computer and Instructional Technology (CEIT) in 2002. In 2005, he received his M.S and he received his Ph.D. in Computer Engineering, University of Trakya. He has been working at Department of CEIT, Faculty of Education at Trakya University as an Assistant Professor. He has an interest in the study of teacher education, technology acceptance, social networks and distance education.

Assist. Prof. Dr. Hasan OZGUR

Trakya University Faculty of Education Department

of Computer Education and Instructional Technologies

Faculty of Education, Kosova Campus Aysekadin, Edirne, TURKEY

Phone: +902842120808

Fax: +902842146279

Email: hasanozgur@gmail.com

\section{REFERENCES}

Agatston, P. W., Kowalski, R., \& Limber, S. (2007). Student's perspective on cyber bullying. Journal of Adolescent Health, 41(6), 59-60.

Akbulut, Y., Sahin, Y. L., \& Eristi, B. (2010). Development of a scale to investigate cybervictimization among online social utility members. Contemporary Educational Technology, 1(1), 46-59. 
Akbulut, Y., \& Eristi, B. (2011). Cyberbullying and victimisation among Turkish university students. Australasian Journal of Educational Technology, 27(7), 1155-1170.

Aricak, O. T. (2009). Psychiatric symptomatology as a predictor of cyberbullying among university students. Eurasian Journal of Educational Research, 34, 167-184.

Aricak, O. T., Kinay, H., \& Tanrikulu, T. (2012). Initial psychometric findings of cyberbullying scale. Journal of the Hasan Ali Yucel Faculty of Education, 17, 340-341.

Aricak, O. T., Tanrikulu, T., \& Kınay, H. (2012). Initial psychometric findings of cybervictimization scale. Mediterranean Journal of Educational Research, 6(11), 1-6.

Aricak, O. T. (2011). Cyberbullying: The new danger waiting for adolescents. Career Window [Kariyer Penceresi], November-December (6), 10-11.

Aricak, T., Siyahhan, S., Uzunhasanoglu, A., Saribeyoglu, S., Ciplak, S., Yilmaz, N., \& Memmedov, C. (2008). Cyberbullying among Turkish adolescents. Cyberpsychology \& Behavior, 11(3), 253-261.

Ayas, T., \& Horzum, M. B. (2011). Exploring the teachers' cyber bullying perception in terms of various variables. International Online Journal of Educational Sciences, 3(2), 619-640.

Ayas, T., \& Horzum, M. B. (2012). On being cyber bully and victim among primary school students. Elementary Education Online, 11(2), 369-380.

Bauman, S. (2010). Cyberbullying in a rural intermediate school: An exploratory study. The Journal of Early Adolescence, 30(6), 803-833.

Bauman, S., \& Pero, H. (2010). Bullying and cyberbullying among deaf students and their hearing peers: An exploratory study. Journal of Deaf Studies and Deaf Education, 16(2), 236-253.

Belsey, B. (2007). Cyberbullying: A real and growing threat. ATA Magazine, 88(1), 14-21. Beran, T., \& Li, Q. (2005). Cyber harassment: A study of new method for an old behavior. Journal of Educational Computing Research, 32(3), 265-277.

Burnukara, P. (2009). İlk ve orta ergenlikte geleneksel ve sanal akran zorbalığına ilişkin betimsel bir inceleme [A descriptive study on traditional and cyber bullying in early and middle adolescence]. (Master's dissertation). Hacettepe University Graduate School of Social Sciences, Ankara, Turkey. Available from the Council of Higher Education, National Dissertation Center, Dissertation ID: 258361.

Campbell, M. A. (2005). Cyber bullying: An old problem in a new guise? Australian Journal of Guidance and Counselling, 15, 68-76.

Campbell, M., Spears, B., Slee, P., Butler, D., \& Kift, S. (2012). Victims' perceptions of traditional and cyberbullying, and the psychosocial correlates of their victimisation. Emotional and Behavioral Difficulties, 17(3-4), 389-401.

Calvete, E., Orue I., Estévez, A., Villardón, L., \& Padilla, P. (2010). Cyberbullying in adolescents: Modalities and aggressors' profile. Computers in Human Behavior 26, 11281135.

Ceyhan, A. A., \& Ceyhan, E. (2008). Loneliness, depression and computer self-efficacy as predictors of problematic internet use. CyberPsychology \& Behavior, 11, 699-701. 
Chak, K., \& Leung, L. (2004). Shyness and locus of control as predictors of Internet addiction and Internet use. CyberPsychology \& Behavior, 7, 559-570.

Çelik, S., Atak, H., \& Erguzen, A. (2012). The effect of personality on cyberbullying among university students in Turkey. Eurasian Journal of Educational Research, 49, 129-150.

Cetin, B., Yaman, E., Peker, A. (2011). Cyber victim and bullying scale: A study of validity and reliability. Computers \& Education, 57, 2261-2271.

http://dx.doi.org/10.1016/j.compedu.2011.06.014

Cetinkaya, B. (2010). İlköğretim ikinci kademe öğrencilerinde siber zorbalığın yaygınlığı [The prevalence of the cyberbullying on secondary school students]. (Master's dissertation). Selcuk University Graduate School of Educational Sciences, Konya, Turkey. Available from the Council of Higher Education, National Dissertation Center, Dissertation ID: 264388.

Erdur-Baker, 0. (2010). Cyber bullying and its correlation to traditional bullying, gender and frequent and risky usage of internet mediated communication tools. New Media and Society, 12, 109-125.

Erdur-Baker, 0., \& Kavsut, F. (2007). Cyber bullying: a new face of peer bullying. Eurasian Journal of Educational Research, 27, 31-42.

EU Kids Online (October, 2012). EU Kids Online: Turkish National perspectives. Retrieved January 05, 2013 from http://eukidsonline.metu.edu.tr/file/PerspectivesReport.pdf

Gezgin, D. M., \& Cuhadar, C. (2012). Bilgisayar ve öğretim teknolojileri eğitimi bölümü öğrencilerinin siber zorbalığa ilişkin duyarlılık düzeylerinin incelenmesi [Investigation of the computer education and instructional technologies students' awareness to cyberbullying]. Journal of Educational Sciences Research, 2(2), 93-104.

Hinduja, S., \& Patchin, J. W. (2008). Cyberbullying: An exploratory analysis of factors related to offending and victimization. Deviant Behavior, 29,129-156.

Hinduja, S., \& Patchin, J. W. (2010). Cyberbullying identification, prevention, and response. Retrieved September 17, 2013 from

http://www.cyberbullying.us/Cyberbullying_Identification_Prevention_Response_Fact_ Sheet.pdf

Hoff, D. L., \& Mitchell, S. N. (2009). Cyberbullying: causes, effects, and remedies. Journal of Educational Administration, 47(5), 652-665.

Huang, Yun-yin, Chou, C. (2013). Revisiting cyberbullying: Perspectives from Taiwanese teachers. Computers \& Education, 63, 227-239.

http://dx.doi.org/10.1016/j.compedu.2012.11.023

Johnson, C. L. (2011). An examination of the primary and secondary effects of cyberbullying: Development and testing of a cyber-bullying moderator/mediator model. (Doctoral dissertation). Available from ProQuest Dissertations and Theses database. (UMI No. 868683577).

Karasar, N. (2008). Bilimsel Araştırma Yöntemi Kavram-İlke-Teknikler [Concept-PolicyTechniques for Scientific Research Method] (18th Edition). Ankara: Nobel Yayınevi.

Keith, S., \& Martin, M. E. (2005). Cyber-Bullying: Creating a culture of respect in a cyberworld. Reclaiming Children and Youth, 13(4), 224-228. 
Kowalski, R. M., \& Limber, S. P. (2007). Electronic bullying among middle school students. The Journal of Adolescent Health, 41(6), 522-530.

Lacey, B. (2007). Social aggression: A study of internet harassment. Hofstra University, New York. (Doctoral dissertation). Available from ProQuest Dissertations and Theses database (UMI No. 304851762).

Li, Q. (2005) Cyber-harassment: A study of a new method for an old. Behavior. Journal of Educational Computing Research, 32(3) 265-277.

Li, Q. (2006). Cyberbullying in schools: A research of gender differences. School Psychology International, 27(2), 157-170.

Mark, L. K. (2009). Student, educator, and parent perceptions of cyberbullying in three Hawai 'i middle schools. (Doctoral dissertation). University of Hawai'i at Manoa, Hawaii. Available from ProQuest Dissertations and Theses database (UMI No. 304894298).

Mason, K. (2008). Cyberbullying: A preliminary assessment for school personnel. Psychology in the Schools, 45(4), 323-348.

Mesch, G. S. (2009). Parental mediation, online activities, and cyberbullying. Cyberpsychology \& Behavior, 12, 217-223.

Ozdemir, M., \& Akar, O. (2011). Examination of high school students' opinions on cyberbullying in terms of various variables. Educational Administration: Theory and Practice, 17(4), 605-626.

Ozdemir, M., \& Akar, F. (2011). Lise öğrencilerinin siber-zorbalığa ilişkin görüşlerinin bazı değişkenler bakımından incelenmesi [Examination high school students' perceptions about cyber-bullying in terms of some variables]. Educational Administration: Theory and Practice, 17(4), 605-626.

Patchin, J. W., \& Hinduja, S. (2010). Cyberbullying and self-esteem. Journal of School Health 80, 614-21.

Peker, A., \& Eroglu, Y., (2010). Internet addiction as a predictor of being a cyberbully/victim of male students. In A. M. Sünbül, \& İ. Şahin (Eds.), 4th International Computer and Instructional Technologies Symposium (ICITS'10), 2010 (pp. 862-867). Konya: Selcuk University Press.

Peker, A., Eroglu, Y., \& Citemel, N. (2012). Relationship of submissive behavior and cyberbullying/cybervictimization: The mediation role of gender. International Journal of Human Sciences, 9(1), 205-221.

Pepler, D. J., Craig, W. M., Connolly, J. A., Yuile, A., McMaster, L., \& Jiang, D. (2006). A developmental perspective on bullying. Aggressive Behavior, 32, 376-384.

Price, M., \& Dalgleish, J. (2010). Cyberbullying: Experiences, impacts and coping strategies as described by Australian young people. Youth Studies Australia 29(2), 51-59. Shariff, S. (2009). Confronting Cyberbullying: What Schools Need to Know to Control Misconduct and Avoid Legal Consequences. New York: Cambridge University Press.

Slonje, R., \& Smith, P. K. (2008). Cyberbullying: Another main type of bullying? Scandinavian Journal of Psychology, 49, 147-154. 
Sahin, M., Sari, S. V., Ozer, O., \& Er, S. H. (2010). High school students' views about their cyber bully behaviors and self-exposition. SDU Faculty of Arts \& Sciences Journal of Social Sciences, 21, 257-270.

Sahin, M. (2012). The relationship between the cyberbullying/cyber victimization and loneliness among adolescents. Children and Youth Services Review 34(4), 834-837.

Tanrikulu, T., Kinay, H., \& Aricak, O., T. (2013). Cyberbullying sensibility scale: Validity and reliability study. Trakya University Journal of Education, 3(1), 38-47.

Topcu, C., Erdur-Baker, O., \& Capa-Aydin, Y. (2008). Examination of cyberbullying experiences among Turkish students from different school types. CyberPsychology \& Behavior, 11(6), 643-648.

Turkish Statistical Institute-TUIK (2012). 2012, Information and communication technology (ICT) usage survey on households and individuals. Retrieved February 06, 2013 from http://www.turkstat.gov.tr/PreHaberBultenleri.do?id=10880

Walrave, M., \& Heirman, W. (2011). Cyberbullying: Predicting victimisation and perpetration. Children \& Society, 25(1), 59-72.

Willard, N. (2005). Educator's guide to cyberbullying addressing the harm caused by outline social cruelty. Retrieved September 13, 2013 from http://www.asdk12.org/MiddleLink/AVB/bully_topics/EducatorsGuide_Cyberbullying.pd f

Wolak, J., Mitchell, K., \& Finkelhor, D. (2007). Does online harassment constitute bullying? An exploration of online harassment by known peers and online-only contacts. Journal of Adolescent Health, 41, 51-58.

Yaman, E., Eroglu, Y., \& Peker, A. (2011). Başa çıkma stratejileriyle okul zorbalığı ve siber zorbalık [Coping strategies, school bullying and cyber-bullying]. Istanbul: Kaknus Psikoloji Press.

Ybarra, M. L., \& Mitchell, K. J. (2004). Youth engaging in online harassment: Associations with caregiver-child relationships, Internet use, and personal characteristics. Journal of Adolescence, 27(3), 319-336.

Ybarra, M., L., Mitchell, K. J., Finkelhor, D., \& Wolak, J. (2007). Internet prevention messages: Targeting the right online behaviors. Archives of Pediatrics \& Adolescent Medicine, 161, 138-145.

Ybarra, M. L., Mitchell, K., J., Wolak, J., \& Finkelhor, D. (2006). Examining characteristics and associated distress related to internet harassment: Findings from the second youth Internet safety survey. Pediatrics, 118, 1169-1177. 